\title{
APPLICATION OF MULTIVARIATE PRINCIPAL COMPONENT ANALYSIS TO MORPHOLOGICAL CHARACTERIZATION OF INDIGENOUS GOATS IN SOUTHERN NIGERIA
}

\author{
Moses OKPEKU 1, 2, , Abdulmojeed YAKUBU ${ }^{3, \#, ~ S u n d a y ~ O l u s o l a ~ P E T E R S ~}{ }^{2,4}$, \\ Michael Ohiokhuaobo OZOJE ${ }^{2}$, Christian Obiora Ndubuisi IKEOBI ${ }^{2}$, \\ Olufunmilayo Ayoka ADEBAMBO ${ }^{2}$, Ikhide Godwin IMUMORIN ${ }^{4}$ *
}

Received July 22, 2011; accepted September 15, 2011.

Delo je prispelo 22. julija 2011, sprejeto 15. septembra 2011.

\begin{abstract}
Application of multivariate principal component analysis to morphological characterization of indigenous goats in Southern Nigeria

Phenotypic variation present in a population arises due to genotypic and environmental effects, and the magnitude of phenotypic variability differs under different environmental conditions, therefore, the purpose of this study was to objectively describe the linear type traits of extensively managed mature indigenous goats of Southern Nigeria and to predict body weight from their orthogonal shape characters using principal component analysis. Body weight and four body measurements namely, height at withers, neck length, body length and heart girth were measured in 265 randomly selected West African Dwarf (WAD) and Red Sokoto (RS) goats of both sexes. RS goats had significantly $(\mathrm{P}<0.05)$ higher morphological traits compared to their WAD counterparts. Sexual dimorphism was observed in all the traits with higher values recorded for males. Phenotypic correlations among body weight and biometric traits were positive and highly significant $(\mathrm{r}=0.76-0.91$ versus $0.82-0.97$ and $0.66-0.94$ versus $0.83-0.91$ for WAD and RS female and male goats, respectively). In the varimax rotated principal component factor analysis, two factors were extracted for each sex of the two breeds, although with varying degrees of factor loadings. The principal component based regression models, which are preferable for selecting animals for optimal balance, accounted for 89.00 and $96.00 \%$ as well as 81.00 and $91.00 \%$ of the variation in body weight of female and male WAD and RS goats, respectively. The information obtained could be useful in designing appropriate management, selection and breeding programmes for utilization of goat genetic resources.
\end{abstract}

Key words: goats / autochthonous breeds / body traits / multivariate analysis / Nigeria

\section{Uporaba multivariatne analize glavnih komponent pri morfo-} loški karakterizaciji avtohtonih koz v južni Nigeriji

Fenotipska variabilnost v populaciji je pogojena $\mathrm{z}$ delovanjem genetskih in okoljskih dejavnikov. Ker je obseg fenotipske variabilnosti različen $\mathrm{v}$ različnih okoljih, smo skušali $\mathrm{v}$ tej študiji objektivno predstaviti linearne eksterierne lastnosti ekstenzivno vzrejanih avtohtonih koz $\mathrm{v}$ južni Nigeriji in $\mathrm{z}$ analizo glavnih komponent napovedati telesno maso na osnovi lastnosti, ki opredeljujejo njihovo telesno obliko. Izmerili smo telesno maso in štiri telesne mere (višina v vihru, dolžina vratu, dolžina trupa in obseg prsi) pri 265 naključno izbranih zahodno afriških pritlikavih kozah (West African Dwarf, WAD) in rdečih sokoto kozah (Red Sokoto, RS) obeh spolov. Vrednosti za merjene lastnosti so bile pri RS kozah statistično značilno $(\mathrm{p}<0,05)$ večje kot pri WAD kozah. Spolni dimorfizem smo zabeležili pri vseh lastnostih, z večjimi vrednostmi za samce. Fenotipske korelacije med telesno maso in biometričnimi lastnostmi so bile pozitivne in statistično visoko značilne ( $\mathrm{r}=0,76-0,91$ in $0,82-0.97$ ter $0,66-0,94$ in $0,83-0,91 \mathrm{za}$ WAD in RS živali ženskega ter moškega spola). S faktorsko analizo z Varimax rotacijo smo za vsako od obeh pasem in vsak spol dobili po dva faktorja. Regresijski modeli, ki temeljijo na analizi glavnih komponent in so primerni za selekcijo živali, so pojasnili 89,00 in $96,00 \%$, ter 81,00 in $91,00 \%$ variance telesne teže ženskih in moških živali pasem WAD in RS. Zbrane informacije bodo uporabne pri upravljanju, selekciji in načrtovanju rejskih programov za boljše izkoriščanje genskih virov pri kozah.

Ključne besede: koze / avtohtone pasme / telesne mere / multivariantna analiza / Nigerija

\footnotetext{
1 Niger Delta Univ., Dept. of Livestock Production Wilberforce Island, P.M.B. 071, Amassoma, Bayelsa State, Nigeria

2 Univ. of Agriculture, Dept. of Animal Breeding and Genetics, Abeokuta, P.M.B. 2240, Abeokuta, Nigeria

3 Nasarawa State Univ., Dept. of Animal Science, Fac. of Agriculture, Lafia Campus, P.M.B. 135, Lafia, Nigeria

4 Cornell Univ., Dept. of Animal Science, 267 Morrison Hall, Ithaca, NY 14853, USA

\# Both authors contributed equally to this paper.

Correspondence: Dr. Ikhide Godwin Imumorin, Dept. of Animal Science, Cornell Univ., Ithaca, NY 14853, USA, Tel: +1 607-255-2850, Fax: +1 607-255-9829, E-mail: igi2@cornell.edu
} 


\section{INTRODUCTION}

Livestock of different species fulfill different functions in the household economy and poor families often keep a diversity of species for this reason (Anderson, 2003). Domestic goats (Capra hircus, L.) are important and adaptable domesticated animals (Abdel Aziz, 2010). They provide a full range of useful products to humans including meat, milk, skin and hair. They efficiently survive on available shrubs and trees in adverse harsh environment and in low fertility lands where no other crops can be grown in Nigeria. Goat production over the years is one of the major means of improving the livelihoods of poor livestock keepers, reducing poverty and attaining sustainable agriculture and universal food security ( $\mathrm{Ab}$ del Aziz, 2010). The population of goats in Nigeria is estimated at 53.8 million (FAOSTAT, 2011) of which traditionally reared stock contributes $99.97 \%$, while $0.03 \%$ of the stock is commercially managed. Based on morphology, the two most important goat breeds traditionally recognized in Nigeria are the Red Sokoto (RS) and the West African Dwarf (WAD) goats, respectively (Ebozoje and Ikeobi, 1998). The WAD goat, which is trypanotolerant, is native to the southern rain forest and derived savanah zones while the RS goat, highly reputed for its quality skin (found more in the northern axis) is more widely distributed across the country.

The diversity in gene pool and influence of varied climatic conditions have given rise to different local populations of goats which are repositories of unique genes that should be conserved for local and international future benefits (Adebambo, 2004). According to Groeneveld et al. (2010), identifying and understanding a unique genetic resource in a particular region and the development and proper use of the associated diversity is a global responsibility. Breed characterization has accordingly been recognized as the first approach to the sustainable use of animal genetic resource (Lanari et al., 2003). It is believed that various breed characteristics provide to some extent reasonable economic indicators. Body size and shape are important traits in meat animals. The characterization of local genetic resources depends on the knowledge of the variation of morphological traits, which have played a very fundamental role in classification of livestock based on size and shape (Ferra et al., 2010; Agga et al., 2010; Leng et al., 2010; Yakubu et al., $2010 \mathrm{a}$ and $\mathrm{b})$. Based on body conformation, meat production can better be estimated than other production properties making body measurements important selection criteria (Bene et al., 2007).

However, the biological relationships among the morphological traits may be different if these body measurements are treated as bivariates rather than mul- tivariates. Principal component analysis is a multivariate technique which could be used with success when morphological variables are interdependent. Principal components are a weighted linear combination of correlated variables, explaining a maximal amount of variance of the variables (Truxillo, 2003). This aids in data reduction, and breaks multicollinearity which may lead to wrong inferences. Many researhers have used the independent factor scores derived from multivariate technique of principal component factor analysis to estimate body weight (Yakubu and Ayoade, 2009), functional traits (Karacaoren and Kardamideen, 2008), and as a selection criterion for the improvement of body size (Pinto et al., 2006). This technique has also been used to reduce the number of independent variables in the prediction of genomic breeding values (Macciotta and Gaspa, 2009). In Sub-Saharan Africa, there is dearth of information on the interrelationships among body weight and morphometric traits of goats using a multivariate approach.

This study was aimed at providing objective description of body shape of WAD and RS goats in southern Nigeria using principal components. It also tested the hypothesis that the relationships involving body weight and morphological traits may be different when orthogonal conformation traits derived from the principal component factor analysis are used instead of the inter-correlated original morphological variables. The information obtained would be helpful to researchers and livestock producers with policies to assist conservation and sustainable utilization of the local goat genetic resources by the proper use of morphological traits.

\section{MATERIALS AND METHODS}

\subsection{LOCATION OF STUDY AND ANIMALS}

The study was carried out in five randomly selected states in southern Nigeria; namely Ogun, Oyo, Bayelsa, Delta and Rivers States, respectively. This region lies between the derived guinea savannah and the dense rain forest, bordered by the Atlantic Ocean.

Two hundred and sixty five mature goats comprising 118 West African Dwarf (WAD) (83 females and 35 males) and 147 Red Sokoto (RS) (37 females and 112 males) goats were randomly sampled in towns and villages. The animals were up to 24 months old as determined by dentition as described by Wilson and Durkin (1984). The goats originated from different flocks and were reared under the traditional extensive system. 


\subsection{TRAITS MEASURED}

The following measurements were taken on each animal:

Body weight (BWT): This was taken using a hanging scale. The animals were turned on their back in a Hessian bag and the weight taken as the difference between the final combined weight and the weight of the bag.

Height at withers (HW): A flat platform was used upon which the animal was placed. The height at withers was measured as the distance from the surface of the platform to the withers using a measuring stick.

Neck length (NL): The neck length was taken as a measure from the base of the skull to the point of connection with the trunk using a tape-rule.

Body length (BL): Body length was measured using a tape-rule, as the distance from the occipital protuberance to the base of the tail.

Heart girth (HG): The heart girth was measured by taking the measurement of the circumference of the chest with a tape-rule.

\subsection{STATISTICAL ANALYSIS}

The morphological traits were subjected to analysis of variance to determine genotype and sex effects. Means were separated using the two-tailed, two-sample t-test. Pearson's coefficients of correlation (r) among body weight and the four morphometric traits were estimated. From the correlation matrix, data were generated for the principal component (PC) factor analysis. The determinant of the correlation matrix was used to test for multicollinearity and singularity. Anti-image correlations, Kaiser-Meyer- Olkin measures of sampling adequacy and Bartlett's Test of Sphericity (to test the null hypothesis that the original correlation matrix is an identity matrix) were computed to test the validity of the factor analysis of the data sets. The appropriateness of the factor analysis was further tested using communalities and ratio of cases to variables. Principal component analysis according to Everitt et al. (2001) is a method for transforming variables in a multivariate data set into new variables, which are uncorrelated with each other and account for decreasing proportions of the total variance of the original variables. The components themselves are merely weighted linear combinations of the original variables. Cumulative proportion of variance criterion was employed in determining the number of principal components to extract. Reproduced and residual correlations were used to test the validity of the number of factors extracted. The varimax criterion of the orthogonal rotation method was employed in the rotation of the factor matrix to enhance the interpretability of the principal components.

The stepwise multiple regression procedure was used to obtain models for predicting body weight from body measurements (1) and from principal component factor scores (2):

$\mathrm{BW}=\mathrm{a}+\mathrm{B}_{\mathrm{i}} \mathrm{X}_{\mathrm{i}}+\ldots+\mathrm{B}_{\mathrm{k}} \mathrm{X}_{\mathrm{k}}$

$\mathrm{BW}=\mathrm{a}+\mathrm{B}_{\mathrm{i}} \mathrm{PC}_{\mathrm{i}}+\ldots+\mathrm{B}_{\mathrm{k}} \mathrm{PC}_{\mathrm{k}}$

where BW is the body weight, $\mathrm{a}$ is the regression intercept, $B_{i}$ is the $i$-th partial regression coefficient of the $i$-th linear body measurement, $\mathrm{X}_{\mathrm{i}}$ or the $\mathrm{i}$-th principal component (PC).

The factor programme of SPSS (2001) statistical package was used for the principal component analysis.

\section{RESULTS AND DISCUSSION}

\subsection{BODY WEIGHT AND MORPHOLOGY TRAITS}

Descriptive statistics of body weight and morphometric traits of WAD and RS goats are presented in Table 1 . Average body weight was significantly $(\mathrm{P}<0.05)$ higher in RS than in WAD goats. Overall body linear measurements for the RS were also higher $(\mathrm{P}<0.05)$ for the RS goats compared to their WAD counterparts. All morphometric traits estimated in this study were higher in males compared to female animals. The higher body measures of RS goats imply that they are heavier, taller and longer breed compared to WAD. Dossa et al. (2007) reported higher average values of $56.57 \mathrm{~cm}$ and $79.23 \mathrm{~cm}$ for $\mathrm{HW}$ and $\mathrm{BL}$ respectively for Benin goat populations compared to $54.46 \mathrm{~cm}$ and $49.89 \mathrm{~cm}$ respectively in Nigerian goats. The large differences in BL between Nigerian and Benin goats may be partially explained by both different methodologies used in measurements and inherent genetic and gene-by-environment differences.

Sexual dimorphism can be phenotypically expressed as differences in skeletal size and/or body mass. The larger values reported for the conformation traits of males compared to females are in agreement with earlier reports on goats (Vargas et al., 2007), sheep (Yakubu and Akinyemi, 2010) and cattle (Polak and Frynta, 2010), respectively. The influence of sex on the body weight and morphometric traits in this study are likely connected with the usual between-sex hormonal action which leads to differential growth rates. Isaac et al. (2005) reported that sexual dimorphism in body size is clearly widespread among many mammalian taxa, with male-biased dimorphism being the more common, but certainly not the exclusive pattern. However, Bacchi et al., (2010) found no 
Table 1: Descriptive statistics of the morphological traits of Nigerian goats based on genotype and sex Preglednica 1: Opisna statistika morfoloških lastnosti nigerijskih koz ob upoštevanju genotipa in spola

\begin{tabular}{|c|c|c|c|c|c|c|c|c|c|c|c|c|}
\hline \multirow{2}{*}{$\begin{array}{l}\text { Traits } \\
\text { Lastnosti }\end{array}$} & \multicolumn{3}{|l|}{ WAD } & \multicolumn{3}{|c|}{ Red Sokoto } & \multicolumn{3}{|l|}{$\begin{array}{l}\text { Female } \\
\text { Ženske }\end{array}$} & \multicolumn{3}{|l|}{$\begin{array}{l}\text { Male } \\
\text { Moški }\end{array}$} \\
\hline & Mean & SE & $\mathrm{SD}$ & Mean & SE & $\mathrm{SD}$ & Mean & SE & $\mathrm{SD}$ & Mean & SE & $\mathrm{SD}$ \\
\hline $\mathrm{BW}$ & $15.37^{\mathrm{b}}$ & 0.38 & 4.14 & $18.99^{\mathrm{a}}$ & 0.36 & 4.41 & $15.58^{\mathrm{b}}$ & 0.34 & 3.76 & $18.86^{\mathrm{a}}$ & 0.40 & 4.79 \\
\hline HW & $47.88^{\mathrm{b}}$ & 0.50 & 5.47 & $61.04^{\mathrm{a}}$ & 0.54 & 6.64 & $50.74^{\mathrm{b}}$ & 0.68 & 7.42 & $58.89^{\mathrm{a}}$ & 0.70 & 8.48 \\
\hline NL & $19.06^{\mathrm{b}}$ & 0.37 & 3.99 & $24.15^{\mathrm{a}}$ & 0.57 & 6.99 & $19.43^{b}$ & 0.35 & 3.80 & $23.91^{\mathrm{a}}$ & 0.60 & 7.29 \\
\hline $\mathrm{BL}$ & $44.86^{\mathrm{b}}$ & 0.50 & 5.40 & $57.89^{\mathrm{a}}$ & 0.53 & 6.47 & $47.32^{\mathrm{b}}$ & 0.65 & 7.11 & $56.05^{\mathrm{a}}$ & 0.67 & 8.16 \\
\hline HG & $58.21^{\mathrm{b}}$ & 0.60 & 6.47 & $65.95^{\mathrm{a}}$ & 0.69 & 8.44 & $59.12^{\mathrm{b}}$ & 0.65 & 7.13 & $65.31^{\mathrm{a}}$ & 0.71 & 8.60 \\
\hline
\end{tabular}

BW - body weight / telesna masa, WH - withers height / višina vihra, NL - neck length / dolžina vratu, BL - body length / dolžina trupa, HG - Heart girth / obseg prsi, SE - standard error / standardna napaka, SD - standard deviation / standardni odklon

a,b Means in the same row bearing different superscripts are significantly different $(\mathrm{P}<0.05)$ / Povprečja v vsaki vrsti, označena $\mathrm{z}$ različnimi črkami, se značilno razlikujejo $(\mathrm{p}<0,05)$.

sexual dimorphism in the morphometric characters considered in Lama guanicoe guanicoe in Argentina. Yakubu (2009) reported that the morphological traits of male and female goats were similar, although this submission were for kids compared to data reported for relatively mature animals in the present study.

\subsection{PHENOTYPIC CORRELATIONS}

Pearson's coefficients of correlation among the various linear type traits for WAD and RS goats are shown in Tables 2 and 3, respectively. In WAD goats, the highest correlation between BW and linear body measurements was recorded for BW and HW in males $(r=0.97)$ and between $\mathrm{BW}$ and $\mathrm{HG}$ in females $(\mathrm{r}=0.91)$. In RS goats, however, the highest correlation was between $\mathrm{BW}$ and chest circumference in both sexes $(r=0.94$ and 0.91 ;

Table 2: Phenotypic correlations among body weight and linear body measurements of WAD goats according to sex *

Preglednica 2: Fenotipske korelacije med telesno maso in linearnimi meritvami pri WAD kozah glede na spol *

\begin{tabular}{llllll}
\hline Traits & BW & WH & NL & BL & HG \\
\hline BW & & 0.86 & 0.76 & 0.91 & 0.91 \\
WH & 0.97 & & 0.80 & 0.93 & 0.81 \\
NL & 0.82 & 0.88 & & 0.86 & 0.72 \\
BL & 0.95 & 0.98 & 0.91 & & 0.84 \\
HG & 0.95 & 0.93 & 0.80 & 0.90 & \\
\hline
\end{tabular}

BW - body weight / telesna masa, WH - withers height / višina vihra, $\mathrm{NL}$ - neck length / dolžina vratu, BL - body length / dolžina trupa, HG - Heart girth / obseg prsi;

* Significant at $\mathrm{P}<0.01$ for all correlation coefficients / Značilno pri $\mathrm{p}<0,01$ za vse korelacijske koeficiente.

Upper matrix: Female goats / Zgornja matrika: ženske živali.

Lower matrix: Male goats / Spodnja matrika: moške živali.
Table 3: Phenotypic correlations among body weight and linear body measurements of RS goats according to sex *

Preglednica 3: Fenotipske korelacije med telesno maso in linearnimi meritvami pri RS kozah glede na spol *

\begin{tabular}{llllll}
\hline Traits & BW & WH & NL & BL & HG \\
\hline BW & & 0.76 & 0.66 & 0.81 & 0.94 \\
WH & 0.85 & & 0.71 & 0.80 & 0.80 \\
NL & 0.90 & 0.79 & & 0.57 & 0.67 \\
BL & 0.83 & 0.85 & 0.76 & & 0.83 \\
HG & 0.91 & 0.84 & 0.81 & 0.86 & \\
\hline
\end{tabular}

BW - body weight / telesna masa, WH - withers height / višina vihra, $\mathrm{NL}$ - neck length / dolžina vratu, $\mathrm{BL}$ - body length / dolžina trupa, HG - Heart girth / obseg prsi;

* Significant at $\mathrm{P}<0.01$ for all correlation coefficients / Značilno pri $\mathrm{p}<0,01$ za vse korelacijske koeficiente.

Upper matrix: Female goats / Zgornja matrika: ženske živali.

Lower matrix: Male goats / Spodnja matrika: moške živali.

$\mathrm{P}<0.01$ for both female and male animals, respectively). The relationship between BW and NL was lowest in both sexes of WAD goats $(r=0.76$ and 0.82 in female and male animals, respectively). While the lowest correlation was equally reported for BW and NL in female RS goats $(\mathrm{r}=0.66)$, that between BW and BL was observed to be lowest in their male counterparts $(\mathrm{r}=0.83)$. The correlation coefficients among body measurements were positive and significant $(\mathrm{P}<0.01)$ in both sexes of the two goat breeds. The present estimates are comparable to the range of values recorded for goats in earlier researches (Yakubu, 2009; Sowande et al., 2010). The positive correlations between $\mathrm{BW}$ and morphological traits obtained in the present study indicate that an increase in any one body measurement would result in a corresponding increase in live body weight. The strong relationship existing between $\mathrm{BW}$ and body measurements suggests that either or the combination of these morphological traits 
could be used to estimate live weight in goats fairly well in the situation where weighbridges or scales are not available. The association may also be useful as selection criterion since positive correlations of traits suggest that the traits may be under the same genetic influences.

\subsection{PRINCIPAL COMPONENT MATRIX}

The determinants of the correlation matrix $(0.011$ versus 0.001 , and 0.044 versus 0.018 for female and male WAD and RS goats, respectively) (Tables 4 and 5) were greater than 0.00001 (minimum requirement) while anti - image correlations computed showed that partial correlations were low, indicating that true factors existed in the data of both sexes of the two goat breeds. This was supported by Kaiser-Meyer- Olkin measure of sampling adequacy studied from the diagonal of partial

Table 4: Eigenvalues and share of total variance along with factor loadings and communalities of the body measurements of WAD goats based on sex

Preglednica 4: Eigen vrednosti in delež celokupne variance s korelacijskimi koeficienti ter skupno varianco faktorjev za telesne mere pri obeh spolih WAD koz

\begin{tabular}{lcclccc}
\hline & \multicolumn{3}{l}{ Female } & & \multicolumn{3}{c}{ Male } & \\
\cline { 2 - 3 } Traits & PC1 & PC2 & Communality & PC1 & PC2 & Communality \\
\hline WH & 0.66 & 0.68 & 0.91 & 0.77 & 0.62 & 0.98 \\
NL & 0.91 & 0.37 & 0.96 & 0.45 & 0.88 & 0.99 \\
BL & 0.71 & 0.67 & 0.95 & 0.70 & 0.69 & 0.97 \\
HG & 0.37 & 0.90 & 0.96 & 0.89 & 0.43 & 0.98 \\
Eigenvalue & 3.48 & 0.29 & & 3.70 & 0.21 & \\
\% Variance & 87.00 & 7.15 & & 92.46 & 5.19 & \\
\hline
\end{tabular}

WH - withers height / višina vihra, NL - neck length / dolžina vratu, BL - body length / dolžina trupa, HG - Heart girth / obseg prsi;

PC - principal component / glavna komponenta

Table 5: Eigenvalues and share of total variance along with factor loadings and communalities of the body measurements of Red Sokoto goats based on sex

Preglednica 5: Eigen vrednosti in delež celokupne variance s korelacijskimi koeficienti ter skupno varianco faktorjev za telesne mere pri obeh spolih RS koz

\begin{tabular}{|c|c|c|c|c|c|c|}
\hline \multirow[b]{2}{*}{ Traits } & \multicolumn{2}{|c|}{ Female } & \multirow[b]{2}{*}{ Communality } & \multicolumn{2}{|l|}{ Male } & \multirow[b]{2}{*}{ Communality } \\
\hline & PC1 & PC2 & & $\mathrm{PC} 1$ & PC2 & \\
\hline WH & 0.77 & 0.52 & 0.86 & 0.82 & 0.47 & 0.89 \\
\hline $\mathrm{NL}$ & 0.34 & 0.93 & 0.99 & 0.45 & 0.89 & 0.99 \\
\hline $\mathrm{BL}$ & 0.93 & 0.25 & 0.92 & 0.88 & 0.39 & 0.93 \\
\hline HG & 0.84 & 0.42 & 0.88 & 0.77 & 0.55 & 0.90 \\
\hline Eigenvalue & 3.20 & 0.45 & & 3.46 & 0.26 & \\
\hline$\%$ Variance & 79.89 & 11.36 & & 86.38 & 6.46 & \\
\hline
\end{tabular}

WH - withers height / višina vihra, NL - neck length / dolžina vratu, BL - body length / dolžina trupa, HG - Heart girth / obseg prsi;

PC - principal component / glavna komponenta correlation, revealing the proportion of the variance in the body measurements caused by the underlying factor. This was found to be sufficiently high for all the mormetric traits in WAD (0.84 and 0.81 for female and animals) and RS (0.81 and 0.86$)$ goats, respectively. overall significance of the correlation matrices tested 29 to 1 in RS goats far exceeding the minimum of 5 to 1 standard) was also met as sample size requirement, while estimates of the residual correlation matrix were low enough.

After varimax rotation of the component matrix in WAD goats, two factors were extracted for each sex, and these accounted for $94.15 \%$ (females) and $97.65 \%$ (males) of the total variance. The factor pattern coefficients were used to assess the relative contributions of the various body measurements in determining the numerical value of the corresponding factor (principal component). In female WAD goats, NL and $\mathrm{BL}$ were more associated with the first PC while the second PC had its loadings for HW and HG, respectively. In their male counterparts, PC1 had its loadings for HG, BL and HW while PC2 was solely related to neck length. However, in RS goats, measurements most highly correlated with PC1 were $\mathrm{BL}, \mathrm{HG}$ and $\mathrm{HW}$ (this explained $79.89 \%$ and $86.38 \%$ of the generalized variance of females and males, respectively), and could be termed "body size factor". PC2 was primarily determined by neck length, which accounted for $11.36 \%$ (females) and $6.46 \%$ (males) of the variation. The principal components obtained in the present study could be used alongside other economic parameters in evaluating animals for management purposes. Similar findings have earlier been reported (Sadek et al., 2006; Yakubu et al., 2009; Yakubu et al., 2011). Principal com- 
ponent analysis has also been employed in determining sex-specific differences in size and morphology of bones of North African gazelle species (Andres et al., 2008) and carcass traits of goats (Bonvillani et al., 2010).

Table 6: Principal component factor scores coefficients for the estimation of body weights of breed 1 and breed 2 goats based on sex

Preglednica 6: Regresijski koeficienti glavnih komponent za oceno telesne mase dveh pasem koz glede na spol

\begin{tabular}{|c|c|c|c|c|c|c|c|c|}
\hline \multirow[b]{3}{*}{ Traits } & \multicolumn{4}{|l|}{ WAD } & \multicolumn{4}{|c|}{ Red Sokoto } \\
\hline & \multicolumn{2}{|c|}{ Female } & \multicolumn{2}{|l|}{ Male } & \multicolumn{2}{|c|}{ Female } & \multicolumn{2}{|l|}{ Male } \\
\hline & PC1 & PC2 & PC1 & PC2 & PC1 & PC2 & PC1 & PC2 \\
\hline $\mathrm{WH}$ & 0.15 & 0.24 & 0.44 & -0.08 & 0.27 & 0.13 & 0.52 & -0.23 \\
\hline NL & 1.11 & -0.75 & -0.93 & 1.37 & -0.51 & 1.16 & -0.81 & 1.4 \\
\hline $\mathrm{BL}$ & 0.26 & 0.14 & 0.09 & 0.29 & 0.66 & -0.44 & 0.79 & -0.57 \\
\hline $\mathrm{HG}$ & -0.75 & 1.13 & 1.15 & -0.86 & 0.43 & -0.10 & 0.31 & 0.05 \\
\hline
\end{tabular}

WH - withers height / višina vihra, NL - neck length / dolžina vratu, BL - body length / dolžina trupa, HG - Heart girth / obseg prsi;

\subsection{PRINCIPAL COMPONENT FACTOR SCORES}

The principal component factor score coefficients of female and male WAD and RS goats are presented in Table 6. The factor score coefficients could be used in instead of the original interdependent morphological traits in predicting the body weight of goats.

\subsection{ESTIMATION OF BODY WEIGHT OF GOATS FROM INTERDEPENDENT BODY MEASURE- MENTS AND THEIR INDEPENDENT PRINCI- PAL COMPONENT FACTOR SCORES}

The interdependent original body measurements and their independent principal component scores were used to predict body weight of goats (Tables 7 and 8). The results of the stepwise multiple regression analysis revealed that HG was the single variable of utmost importance in the prediction of BW in both breeds, with the exception of male WAD goats, where HW alone account-

Table 7: Stepwise multiple regression of body weight on original body measurements and on their principal components factor scores of WAD goats

Preglednica 7: Postopna multipla regresija telesne mase na originalne telesne mere in na faktorske vrednosti glavnih component pri WAD kozah

\begin{tabular}{|c|c|c|c|c|c|}
\hline Model & Explanatory variables (predictors) & Intercept & $\begin{array}{l}\text { Regression } \\
\text { Coefficient }\end{array}$ & SE & $\mathrm{R}^{2}$ \\
\hline \multicolumn{6}{|l|}{ Female } \\
\hline (i) & Original body measurements as predictors & & & & \\
\hline 1 & Heart girth & -18.59 & 0.58 & 0.03 & 83.00 \\
\hline \multirow[t]{2}{*}{2} & Heart girth & -20.96 & 0.32 & 0.04 & 90.00 \\
\hline & Body length & & 0.39 & 0.05 & \\
\hline (ii) & Orthogonal traits as predictors & & & & \\
\hline 1 & PC1 & 14.77 & 2.93 & 0.25 & 63.00 \\
\hline \multirow[t]{2}{*}{2} & $\mathrm{PC} 1$ & 14.77 & 2.93 & 0.14 & 89.00 \\
\hline & PC2 & & 1.89 & 0.14 & \\
\hline \multicolumn{6}{|l|}{ Male } \\
\hline (i) & Original body measurements as predictors & & & & \\
\hline 1 & Height at withers & -17.12 & 0.68 & 0.03 & 94.20 \\
\hline \multirow[t]{2}{*}{2} & Height at withers & -19.57 & 0.44 & 0.07 & 96.00 \\
\hline & Heart girth & & 0.24 & 0.06 & \\
\hline (ii) & Orthogonal traits as predictors & & & & \\
\hline 1 & PC2 & 16.81 & 4.00 & 0.46 & 70.00 \\
\hline \multirow[t]{2}{*}{2} & PC2 & 16.81 & 4.00 & 0.16 & 96.40 \\
\hline & $\mathrm{PC} 1$ & & 2.48 & 0.16 & \\
\hline
\end{tabular}

$\mathrm{SE}$ - standard error / standardna napaka, $\mathrm{R}^{2}$ - coefficient of determination / determinacijski koeficient, PC - principal component / glavna komponenta 
Table 8: Stepwise multiple regression of body weight on original body measurements and on their principal components factor scores of Red Sokoto goats

Preglednica 8: Postopna multipla regresija telesne mase na originalne telesne mere in na faktorske vrednosti glavnih component pri RS kozah

\begin{tabular}{|c|c|c|c|c|c|}
\hline Model & Explanatory variables (predictors) & Intercept & $\begin{array}{l}\text { Regression } \\
\text { Coefficient }\end{array}$ & SE & $\mathrm{R}^{2}$ \\
\hline \multicolumn{6}{|l|}{ Female } \\
\hline (i) & Original body measurements as predictors & & & & \\
\hline 1 & Heart girth & -6.58 & 0.39 & 0.02 & 89.00 \\
\hline (ii) & Orthogonal traits as predictors & & & & \\
\hline 1 & PC1 & 17.42 & 2.57 & 0.33 & 63.00 \\
\hline \multirow[t]{2}{*}{2} & $\mathrm{PC} 1$ & 14.42 & 2.57 & 0.24 & 81.00 \\
\hline & PC2 & & 1.34 & 0.24 & \\
\hline
\end{tabular}

Male

(i) Original body measurements as predictors

\begin{tabular}{llllll}
1 & Heart girth & -13.94 & 0.50 & 0.02 & 83.00 \\
2 & Heart girth & -6.94 & 0.29 & 0.03 & 0.03 \\
& Neck length & & 0.29 & & \\
(ii) & Orthogonal traits as predictors & & & & \\
1 & PC2 & & & & \\
2 & PC2 & 19.50 & 3.23 & 32 & 0.14 \\
& PC1 & 19.50 & 3.23 & 3.00 \\
\hline
\end{tabular}

$\mathrm{SE}$ - standard error / standardna napaka, $\mathrm{R}^{2}$ - coefficient of determination / determinacijski koeficient, $\mathrm{PC}$ - principal component / glavna komponenta

ed for $94.20 \%$ of the variation in body weight. However, a combination of HG and BL (females) and HW and HG (males) of WAD goats increased the proportion of the explained variance to $90.00 \%$ and $96.00 \%$, respectively. Similarly, the accuracy of the prediction model was improved $(91.10 \%)$ in male RS goats when NL was added to HG.

The possibility of using simple body measurements that can be carried out in the field to predict important economic traits have been demonstrated (Vargas et al., 2007; Ozkaya and Bozkurt, 2009; Yakubu 2010a and b). Badi et al. (2002) and Leng et al. (2010) recommended the use of heart girth as the most reliable variable to predict BW under field conditions. The importance of $\mathrm{HG}$ in weight estimation could be as a result of the fact that muscle, some fat along with bone structure contribute to its formation. However, the use of interdependent explanatory variables should be treated with caution since multicollinearity has been shown to be associated with unstable estimates of regression coefficients (Malau-Aduli et al., 2004), rendering the estimation of the unique effects of the predictors impossible. This justifies the use of principal component factor scores for prediction. These factors are orthogonal to each other and are more reliable in weight estimation. PC1 and PC2 together accounted for $89.00 \%$ and $96.40 \%$ of the variation in body weight of female and male WAD goats, respectively. In RS goats, a combination of PC1 and PC2 explained $81.00 \%$ (females) and $91.00 \%$ (males) of the total variability in body weight. Similarly, Keskin et al. (2007) and Eyduran et al. (2009) used factor score coefficients to predict carcass and weaning weights, respectively in small ruminants.

\section{CONCLUSIONS}

The principal component factor analysis led to an objective simultaneous analysis of $\mathrm{WH}, \mathrm{NL}, \mathrm{BL}$ and $\mathrm{HG}$ of WAD and RS goats rather than on individual basis. This resulted in the reduction of the body dimensions to two PCs in each sex of the two goat breeds. The resultant factor score coefficients could be used to predict body weight with more accuracy than the original interdependent variables. This is because multicollinearity of two or more independent body measurements could lead to unstable regression coefficients, thereby leading to er- 
roneous inferences. Results of the present investigation could assist farmers and genetic improvement specialists when conducting management, selection and preservation programs in Nigerian goats.

\section{REFERENCES}

Abdul-Aziz., M. 2010. Present status of the world goat populations and their productivity. Lohman information, 45: $42-52$

Adebambo O.A. 2004. Animal genetics and the quality of life. Proceedings of the $29^{\text {th }}$ Annual Conference of the Genetics Society of Nigeria, 11-14 Oct. 2004. Abeokuta, Nigeria, $42-53$

Agga G.E., Udala U., Regassa F., Wudie A. 2010. Body measurements of bucks of three goat breeds in Ethiopia and their correlation to breed, age and testicular measurements. Small Rumin. Res., 95, 2: 133-138

Anderson S. 2003. Animal genetic resources and sustainable livelihoods. Ecological Economics, 45: 331-339

Andres M, Alcalde GM, Azanza B, Morales J, Alberdi MT. 2008. Sex-specific differences of the skeleton in North African gazelles (Mammalia, Artiodactyla, Bovidae). Sexual Development, 2: 279 (Abstract)

Bacchi C.S., Lanari M.R., von Thungen J. 2010. Non-genetic factors affecting morphometric and fleece traits in guanaco (Lama guanicoe guanicoe). Small Rumin. Res., 88: 54-61

Badi A.M.I., Fissehaye N., Rattan P.J.S. 2002. Estimation of live body weight in Eritrean goat from heart girth and height at withers. Indian J. Anim. Sci., 72: 893-895

Bene S., Nagy B., Nagy L., Kiss B., Polgar J.P., Szabo F. 2007. Comparison of body measurements of beef cows of different breeds. Arch. Tierz. Dummerstorf, 50: 363-373

Bonvillani A., Pena F., de Gea G., Gomez G., Petryna A., Perea J. 2010. Carcass characteristics of Criollo Cordobes kid goats under an extensive management system: Effects of gender and liveweight at slaughter. Meat Science, 86, 3: 651-659

Dossa L.H., Wollny C., Gauly M. 2007. Spatial variation in goat populations from Benin as revealed by multivariate analysis of morphological traits. Small Rumin. Res., 73: 150-159

Ebozoje M.O., Ikeobi, C.O.N. 1998. Colour variation and reproduction in the West African Dwarf (WAD) goats. Small Rumin. Res., 27: 125-130

Eyduran E., Karakus K., Karakus S., Cengiz F. 2009. Usage of factor scores for determining relationships among body weight and some body measurements. Bulgarian Journal of Agricultural Science, 15: 373-377

Everitt B.S., Landau S., Leese M. 2001. Cluster analysis. $4^{\text {th }}$ Edition. London, Arnold Publisher

FAOSTAT. 2011. Food and Agricultural Organization of the United Nations. http://faostat.fao.org/default.aspx (19. Jul. 2011)

Ferra J.C., Cieslak S., Filho R.S., McManus C., Martins C.L., Sereno J.R.B. 2010. Weight and age at puberty and their correlations with morphometric measurements in crossbreed breed Suffolk ewe lambs. Revista Brasileira de Zootecnia, 39: $134-141$
Groeneveld L.F., Lenstra J.A., Eding H., Toro M.A., Scherf B., Pilling D., Negrini R., Finlay E.K., Jianlin H., Groeneveld E., Weigend S., The GLOBALDIV Consortium. 2010. Genetic diversity of farm animals - a review. Animal Genetics, 41 (Suppl 1): 6-31

Isaac J.L. 2005. Potential causes and life-history consequences of sexual size dimorphism in mammals. Mammal Review, 35: 101-115

Karacaoren B, Kadarmideen H.N. 2008. Principal component and clustering analysis of functional traits in Swiss dairy cattle. Turkey Journal of Veterinary and Animal Sciences, 32: $163-171$

Keskin S., Daskiran I., Kor A. 2007. Factor analysis scores in a multiple linear regression model for the prediction of carcass weight in Akkeci kids. J. Appl. Anim. Res., 31: 201-204

Lanari M.R., Taddeo H., Domingo E., Centeno M.P., Gallo L. 2003. Phenotypic differentiation of exterior traits in local Criollo goat population in Patagonia (Argentina). Arch Tierz Dummerstorf, 46: 347-356

Leng J., Zhu R., Zhao G., Yang Q., Mao H. 2010. Quantitative and qualitative body traits of Longling Yellow goats in China. Agricultural Sciences in China, 9: 408-415

Loison A., Gaillard J.M., Pelabon C., Yoccoz N.G. 1999. What factors shape sexual size dimorphism in ungulates? Evolutionary Ecology Research, 1: 611-633

Macciotta N.P.P., Gaspa G. 2009. Use of principal component and factor analysis to reduce the number of independent variables in the prediction of genomic breeding values. Italian J. Anim. Sci. 8 (Supplement 2): 105-107

Malau-Aduli A.E.O., Aziz M.A., Kojina T., Niibayashi T., Oshima K., Komatsu M. 2004. Fixing collinearity instability using principal component and ridge regression analyses in the relationship between body measurements and body weight in Japanese Black cattle. Journal of Animal and Veterinary Advances, 3: 856-863

Ozkaya S., Bozkurt Y. 2009. The accuracy of prediction of body weight from body measurements in beef cattle. Archiv Tierzucht, 52: 371-377

Pinto L.F.B., Dacker I.U., Demelo C.M.R., Ledur M.C., Coutinho L.L. 2006. Principal components analysis applied to performance and carcass traits in the chicken. Animal Research, 55: 419-425

Polak J., Frynta D. 2010. Patterns of sexual size dimorphism in cattle breeds support Rensch' rules. Evolutionary Ecology, 24: $1255-1266$

RIM. 1992. Nigerian Livestock Research, Vol.111, National Synthesis. Report by Resource Inventory and Management Limited (RIM) to Federal Department of Livestock and Pest Control Services, Abuja, Nigeria

Sadek M.H., Al-Aboud A.Z., Ashmawy A.A. 2006. Factor analysis of body measurements in Arabian horses. Journal of Animal Breeding and Genetics, 123: 369-377

Sowande O.S., Oyewale B.F., Iyasere O.S. 2010. Age- and sexdependent regression models for predicting the live weight of West African Dwarf goat from body measurements, TroAnim. Health Prod., 42: 969-975

SPSS. 2001. Statistical Package for Social Sciences. Chicago, SPSS Inc., 444 Michigan Avenue, IL60611 
Truxillo C. 2003. Multivariate Statistical Methods: Practical Research Applications Course Notes. Cary, NC: SAS Institute

Vargas S., Larbi A., Sanchez M. 2007. Analysis of size and conformation of native Creole goat breeds and crossbreds used in smallholder agrosilvopastoral systems in Puebla, Mexico. TroAnim. Health Prod., 39: 279-286

Yakubu A. 2009. Fixing collinearity instability in the estimation of body weight from morphobio-metrical traits of West African Dwarf goats, Trakia J. Sci., 7: 61-66

Yakubu A., Ayoade J.A. 2009. Application of principal component factor analysis in quantifying size and morphological indices of domestic rabbits. International Journal of Morphology, 27: 1013-1017

Yakubu A., Ogah D.M., Idahor K.O. 2009. Principal component analysis of the morphostructural indices of White Fulani cattle. Trakia J. Sci., 7: 67-73

Yakubu A., Salako A.E., Abdullah A-R. 2011. Varimax rotated principal component analysis of the zoometrical traits of Uda sheeArchivos de Zootecnia 60 (On line version)
Yakubu A. 2010a. Path coefficient and path analysis of body weight and biometric traits in Yankasa lambs. Slovak J. Anim. Sci., 43: 17-25

Yakubu A. 2010b. Fixing multicollinearity instability in the prediction of body weight from morphometric traits of White Fulani cows. Journal of Central European Agriculture, 11: 487-492

Yakubu A., Akinyemi M.O. 2010. An evaluation of sexual size dimorphism in Uda sheep using multifactorial discriminant analysis. Acta Agriculturae Scandinavica A-Animal Science, 60: 74-78

Yakubu A., Salako A.E., Imumorin I.G. 2010a. Multivariate analysis of spatial patterns of morphological traits in West African Dwarf goats in three agro-ecological zones of Nigeria. J. Appl. Anim. Res., 38: 257-260

Yakubu, A., Idahor, K.O., Haruna, H.S., Wheto, M. and Amusan, S. 2010b. Multivariate analysis of phenotypic differentiation in Bunaji and Sokoto Gudali cattle, Acta Agriculturae Slovenica, 96: 75-80 